\title{
AKAR RADIKALISME ISLAM DI INDONESIA
}

Oleh: Sun Choirol Ummah, M.S.I.

(MKU - UNY)

\begin{abstract}
Abstrak
"Agama sudah semestinya ditinggalkan manusia bukan karena alasan teologis, tetapi karena agama telah menjadi sumber kekerasan sekarang ini dan pada setiap zaman di masa yang lalu". Ungkapan Harris dalam The End of Faith: Religion: Terror and the Future of Reason ini patut direnungkan karena maraknya berbagai isu kekerasan, bentrokan, permusuhan, di ranah sosial politik pada ujungnya sering berakhir pada permasalahan agama. Agama sangat potensial menyulut api kekerasan tetapi media massa ditengarai juga sangat berperan dalam menyulut api permusuhan ini. Tidak hanya itu, pencarian identitas Muslim yang takkunjung usai serta tekanan sosiopolitik dan sosiohistoris Barat yang merepresentasikan Islam sebagai agama teror, menambah runyam dan buruknya representasi Islam di mata agama lainnya. Untuk itu diperlukan pemahaman bahwa Islam adalah agama perdamaian yang membawa kesejukan bagi agama dan kepercayaan lainnya. "Agama dan kepercayaan boleh berbeda-beda tetapi bertuhan satu jua". Dengan berdasar pada landasan ini diharapkan tidak terjadi "right or wrong is my country", hanya mendaku bahwa agamakulah yang paling benar.
\end{abstract}

\section{Pendahuluan}

Munculnya isu-isu politis mengenai radikalisme Islam merupakan tantangan baru bagi umat Islam untuk menjawabnya. Isu radikalisme Islam ini sebenarnya sudah lama mencuat di permukaan wacana internasional. Radikalisme Islam sebagai fenomena historis-sosiologis merupakan masalah yang banyak dibicarakan dalam wacana politik dan peradaban global akibat kekuatan media yang memiliki potensi besar dalam menciptakan persepsi masyarakat dunia. Banyak label-label yang diberikan oleh kalangan Eropa Barat dan Amerika Serikat untuk menyebut gerakan Islam radikal ini, mulai dari sebutan kelompok garis keras, ekstrimis, militan, Islam kanan, fundamentalisme, sampai terrorisme. Bahkan negara-negara Barat pascahancurnya ideologi komunisme (pascaperang dingin) memandang Islam sebagai sebuah gerakan peradaban yang menakutkan (Nurcholish Madjid, 1995: 270).

Gerakan perlawanan rakyat Palestina, Revolusi Islam Iran, Partai FIS AlJazair, perilaku anti-AS yang dipertunjukkan Mu'ammar Ghadafi ataupun Saddam Hussein, gerakan Islam di Mindanao Selatan, gerakan masyarakat Muslim Sudan yang anti-AS, merebaknya solidaritas Muslim Indonesia terhadap saudara-saudara 
yang tertindas, dan sebagainya adalah fenomena yang dijadikan media Barat dalam mengampanyekan label radikalisme Islam. Dalam perspektif Barat, gerakan Islam sudah menjadi fenomena yang perlu dicurigai. Terlebih-lebih pascahancurnya gedung WTC New York 11 September 2001 yang menurutnya dilakukan oleh kelompok Islam garis keras (Al-Qaeda dan Taliban), semakin menjadikan term radikalisme Islam lebih mengglobal yang berimplikasi pada sikap kecurigaan masyarakat dunia, terutama bangsa Barat dan Amerika Serikat, terhadap gerakan Islam. Hal yang demikian terjadi karena orang-orang Eropa Barat dan Amerika Serikat berhasil melibatkan diri dan mewarnai media sehingga mampu membentuk opini publik. Praktik-praktik kekerasan yang dilakukan sekelompok Islam dengan membawa simbol-simbol agama telah dimanfaatkan oleh orang-orang Barat dengan memanfaatkan media massa sebagai alat utama dalam memegang tampuk wacana peradaban, sehingga Islam terus menerus dipojokkan oleh publik. Fenomena ini digambarkan dalam film Fitna dan penggambaran tentang kiamat (film 2012). Namun, di titik yang berbeda ternyata agama (Islam) justru masuk dan merangsek menjarah wilayah publik. Barangkali masyarakat Barat telah tertipu oleh muslihat peradabannya sendiri dalam mengeksploitasi media yang diciptakannya.

Ketergesa-gesaan dalam generalisasi menyebabkan Barat tidak mampu memandang fenomena historis umat Islam secara objektif. Hal ini tidak berarti pembenaran terhadap praktik radikalisme yang dilakukan umat beragama, karena yang demikian bertentangan dengan pesan-pesan moral yang terkandung dalam agama dan moralitas mana pun. Akan tetapi apa yang perlu dilihat adalah bahwa Islam sebagai agama sangat menjunjung tinggi perdamaian. Hal ini bukan saja ada dalam normativitas teks wahyu dan sunnah tetapi termanifestasi dalam sejarah Islam awal. Islam secara normatif dan historis (era Nabi) sama sekali tidak pernah mengajarkan praktik radikalisme sebagaimana terminologi Barat. Islam tidak memiliki keterkaitan dengan gerakan radikal, bahkan tidak ada pesan moral Islam yang menunjuk kepada ajaran radikalisme baik dari sisi normatif maupun historis kenabian.

\section{Pengertian Radikalisme Islam}

Islam merupakan agama kedamaian yang mengajarkan sikap berdamai dan mencari perdamaian (Nurcholis Madjid, 1995: 260). Sementara yang dimaksud 
dengan radikalisme adalah gerakan yang berpandangan kolot dan sering menggunakan kekerasan dalam mengajarkan keyakinan mereka (Nasution, 1995: 124). Islam tidak pernah membenarkan praktik penggunaan kekerasan dalam menyebarkan agama, paham keagamaan, serta paham politik.Tetapi memang tidak bisa dibantah bahwa dalam perjalanan sejarahnya terdapat kelompok-kelompok Islam tertentu yang menggunakan jalan kekerasan untuk mencapai tujuan politis atau mempertahankan paham keagamaannya secara kaku yang dalam bahasa peradaban global sering disebut kaum radikalisme Islam.

Istilah radikalisme untuk menyebut kelompok garis keras dipandang lebih tepat ketimbang fundamentalisme, karena fundamentalisme sendiri memiliki makna yang interpretable. Dalam perspektif Barat, fundamentalisme berarti paham orangorang kaku ekstrim serta tidak segan-segan berperilaku dengan kekerasan dalam mempertahankan ideologinya. Sementara dalam perspektif Islam, fundamentalisme berarti tajdid (pembaruan) berdasarkan pesan moral Al-Quran dan Sunnah (Imarah, 1999: 22). Dalam tradisi pemikiran teologi keagamaan, fundamentalisme merupakan gerakan untuk mengembalikan seluruh perilaku dalam tatanan kehidupan umat Islam kepada Al-Quran dan Sunnah (Watt, 1998: 2). Fundamentalisme juga berarti anti-pembaratan (westernisme) (Rahman, 1982: 136). Terkadang fundamentalisme diartikan sebagai radikalisme dan terorisme disebabkan gerakan fundamentalisme memiliki implikasi politik yang membahayakan negara-negara industri di Barat (Kuntowijoyo, 1997: 49).

Sebutan fundamentalis memang terkadang bermaksud untuk menunjuk kelompok pengembali (revivalis) Islam (Gibb, 1990: 52). Tetapi terkadang istilah fundamentalis juga ditujukan untuk menyebut gerakan radikalisme Islam. Di media Barat, fundamentalisme berarti intoleran dan kekerasan yang ditopang fanatisme keagamaan (Ahmed, 1993: 30). Sebutan untuk memberikan label bagi gerakan radikalisme bagi kelompok Islam garis keras juga bermacam-macam. M.A. Shaban menyebut aliran garis keras (radikalisme) dengan sebutan neo-Khawarij (Shaban, 1994: 56). Sedangkan Harun Nasution menyebutnya dengan sebutan Khawarij abad kedua puluh satu (abad ke-21) karena memang jalan yang ditempuh untuk mencapai tujuan adalah dengan menggunakan kekerasan sebagaimana dilakukan Khawarij pada masa pasca-tahkim (Nasution, 1995: 125). Istilah radikalisme Islam berasal 
dari pers Barat untuk menunjuk gerakan Islam garis keras (ekstrim, fundamentalis, militan). Istilah radikalisme merupakan kode yang terkadang tidak disadari dan terkadang eksplisit bagi Islam (Ahmed, 1993: 30). Yang menjadi masalah di Barat dan Amerika sebenarnya bukan Islam itu sendiri tetapi praktik-praktik kekerasan yang dilakukan oleh sekelompok komunitas Muslim dalam proses pembentukan jati diri (identitas) kelompoknya (Nurcholish Madjid, 1995: 270).

Dengan demikian, penulis lebih cenderung menggunakan istilah radikalisme dari pada fundamentalisme karena pengertian fundamentalisme dapat memiliki artiarti lain yang terkadang mengaburkan makna yang dimaksudkan sedang radikalisme dipandang lebih jelas makna yang ditunjuknya yaitu gerakan yang menggunakan kekerasan untuk mencapai target politik yang ditopang oleh sentimen atau emosi keagamaan.

Radikalisme merupakan gerakan yang dilakukan oleh individu atau kelompok yang dirugikan oleh fenomena sosio-politik dan sosio-historis. Gejala praktik kekerasan yang dilakukan oleh sekelompok umat Islam itu, secara historissosiologis, lebih tepat sebagai gejala sosial politik ketimbang gejala keagamaan meskipun dengan mengibarkan panji-panji keagamaan. Fenomena radikalisme yang dilakukan oleh sebagian kalangan umat Islam, oleh pers Barat dibesar-besarkan, sehingga menjadi wacana internasional dan terciptalah opini publik bahwa Islam itu mengerikan dan penuh dengan kekerasan. Akibatnya tidak jarang image-image negatif banyak dialamatkan kepada Islam sehingga umat Islam terpojokkan sebagai umat perlu dicurigai. Hal yang demikian terjadi karena masyarakat Barat mampu menguasai pers yang dijadikan instrumen yang kuat guna memroyeksikan kultur dominan dari peradaban global. Apa yang ditangkap masyarakat dunia adalah apa yang didefinisikan dalam media-media Barat. Label Islam untuk menyebut gerakan fundamentalis sangat menyenangkan bagi pers Barat ketimbang label Tamil di Srilangka, militan Hindu di India, IRA (kelompok bersenjata Irlandia Utara), militan Yahudi sayap kanan, sekte kebatinan di Jepang atau bahkan musuh lamanya, komunis-marxis yang tidak jarang menggunakan jalan kekerasan sebagai solusi penyelesaian masalah. Karena terlalu mengkaitkan kata-kata radikalisme, fundamentalis, atau gerakan militan dengan Islam, seringkali media Barat mengabaikan perkembangan praktik kekerasan yang ditopang keyakinan keagamaan 
yang dilakukan oleh kalangan non-Islam atau pun yang ditopang oleh ideologi "kiri." Contoh yang sangat jelas adalah aksi tutup mulut para elit politik Barat atau aksi bicara dalam kepura-puraan ketika melihat praktik kekerasan yang dilakukan oleh ekstrimis Yahudi atau pun serdadu Israel atas orang-orang Arab Palestina. Apa yang dilakukan oleh kelompok-kelompok pelaku kekerasan ini secara faktual sama dengan apa yang dilakukan oleh kelompok pelaku garis keras "radikalisme Islam." Tetapi sebutan radikalisme lebih kental ditujukan kepada gerakan Islam. Hal inilah yang ditolak oleh gerakan negara-negara OKI (Organisasi Konferensi Islam) dalam pertemuannya di Kuala Lumpur Malaysia tanggal 1-3 April 2002.

Realitas historis-sosiologis tersebut merupakan bukti betapa Barat menggunakan standar ganda dan bersikap tidak adil terhadap Islam. Ketika masjid dan Mullah dilihat sebagai simbol radikalisme atau ketika gejala-gejala kultural Muslim diproyeksikan sebagai bentuk fanatisme dan ekstrimisme, terjadilah pengekangan dan pemenjaraan peradaban Islam. Masyarakat Barat telah memberikan klaim peradaban atas Islam, sementara proses peradaban Islam sedang membentuk jati dirinya. Hal yang demikian tidak berarti pembenaran perilaku radikalisme yang dilakukan umat Islam, karena apapun alasannya praktik kekerasan merupakan pelanggaran norma keagamaan sekaligus pelecehan kemanusiaan.

Dengan demikian, jelas bahwa label radikalisme yang dialamatkan oleh Barat kepada Islam merupakan pelecahan agama karena di dalam Islam tidak ada perintah menuju kekerasan. Istilah salah kaprah itu sesungguhnya tidak perlu terjadi jika Barat mau mengkaji Islam secara objektif bahwa Islam normatif terkadang tidak diimplementasikan oleh sekelompok Muslim dalam konteks historis-sosiologis. Islam berbeda dengan perilaku Muslim, artinya kebutralan (radikalisme) yang dilakukan oleh sekelompok Muslim tidak dapat dijadikan alasan untuk menjadikan Islam sebagai biang keladi radikalisme. Sebaliknya, kelompok-sekolompok kecil umat Islam yang fanatik dan mengarah kepada benturan dan kekerasan juga menjadi bahaya besar bagi masa depan peradaban manusia. Gerakan radikalisme yang dilakukan oleh sekelompok orang, termasuk Muslim, merupakan kanker rohani yang kronis yang mengancam manusia dan kemanusiaan. Di luar itu semua, praktikpraktik arogansi Barat dan hegemoninya atas dunia Islam harus juga disadari 
sebagai faktor yang dapat menimbulkan reaksi dalam bentuk radikalisme anti-Barat yang dilakukan oleh sebagian komunitas Muslim.

\section{Akar Radikalisme Islam Indonesia}

Berubahnya sistem pascaruntuhnya Orde Baru 1998 membawa pengaruh yang sangat besar bagi perkembangan berbagai elemen bangsa, termasuk di dalamnya perkembangan Islam. Bentuk Islam di Indonesia menjadi sangat beragam. Keragaman ini tercermin dari jumlah organisasi keislaman dan kelompok kepentingan atas nama Islam yang dari waktu ke waktu semakin bervariasi.

Peter G. Riddel membagi menjadi empat kekuatan Islam Indonesia pasca runtuhnya Orde Baru, yaitu; modernis, tradisionalis, neomodernis dan Islamis. Secara umum, Riddel sepaham terhadap definisi masing-masing kategori dengan mengabaikan satu kategori dari Woodward, yaitu indigenized Islam. Bagi Riddel, masing-masing kategori memiliki ciri khasnya sendiri dalam menanggapi berbagai isu krusial di tahun-tahun periode pertama pascapemilu pertama runtuhnya Orde Baru, yaitu tahun 1999. Isu-isu tersebut antara lain kembali ke Piagam Jakarta, krisis Maluku, membuka hubungan dagang Israel, negara Indonesia federal, tempat kaum minoritas dalam sistem negara Indonesia, presiden perempuan, dan partai politik yang baru dibuka krannya setelah Orde Baru runtuh (Riddel, 2002: 65-83).

Pengelompokan yang dilakukan oleh Riddel di atas bila dilihat dari sisi penafsiran dapat dipersempit menjadi dua pengelompokan saja, yaitu liberalmoderat dan radikal atau fundamental. Islam liberal dan moderat dengan penafsiran terbuka terhadap ajaran Islam, sekalipun tidak sama persis, sedangkan Islam radikal atau fundamentalis memiliki paham penafsiran tertutup. Beberapa kelompok Islam seperti Jaringan Islam Liberal (JIL), Lembaga Kajian dan Pengembangan Sumber Daya Manusia (LAKPESDAM) NU, Jaringan Intelektual Muda Muhammadiyah (JIMM), adalah beberapa kelompok Islam yang dapat dikategorikan ke dalam kelompok Islam yang beraliran terbuka.

Selain Islam liberal, Islam garis keras atau Islam radikal banyak menikmati perubahan politik di Indonesia ini. Islam radikal ini telah berkembang menjadi salah satu kelompok gerakan Islam baru yang mempunyai arti penting di Indonesia. Berbagai kelompok Islam radikal ini muncul. Sebagian adalah gerakan Islam yang berskala internasional seperti gerakan Salafi dan Hizbut Tahrir. Sebagian yang lain 
adalah gerakan berskala nasional seperti Front Pembela Islam, Hizbut Tahrir Indonesia, Lasykar Mujahidin, Ikhwanul Muslimin Indonesia. Selain itu muncul gerakan Islam radikal lokal seperti Front Pemuda Islam Surakarta (FPIS) di Surakarta dan Front Thariqah Jihad (FTJ) di Kebumen.

Radikalisme atau fundamentalisme tidaklah muncul dari ruang hampa. Dalam teori sosial, radikalisme adalah sebuah gerakan yang terkait atau disebabkan oleh fakta lain. Dalam pandangan kaum fakta sosial bahwa ada tiga asumsi yang mendasari keseluruhan cara berpikirnya, yaitu terdapat keajegan atau terdapat keteraturan sosial (social order), terdapat perubahan sekali waktu dan tidak ada fakta yang berdiri sendiri kecuali ada fakta penyebabnya. Akar radikalisme dapat ditilik dari beberapa penyebab, antara lain: pertama, adanya tekanan politik penguasa terhadap keberadaannya. Di beberapa belahan dunia, termasuk Indonesia fenomena radikalisme atau fundamentalisme muncul sebagai akibat otoritarianisme (Azyumardi Azra, 1996: 18). Dalam kasus Orde Baru, negara selalu membabat habis yang diidentifikasi sebagai gerakan radikal. Baginya radikalisme adalah musuh nomer satu dan dijadikan sebagai common enemy melalui berbagai media transformasi. Radikalisme kiri dan kanan sama saja. Radikalisme kiri seperti Gerakan New Left, yang pernah berkembang di Indonesia sekitar tahun 1980-an dan terus memperoleh momentum di tahun 1990-an melalui Partai Rakyat Demokratik (PRD) merupakan eksponen organisasi yang dianggap sebagai musuh negara. Begitu kerasnya tekanan terhadap gerakan radikal kiri ini, banyak para tokohnya yang ditangkap, disiksa, bahkan ada yang hilang tidak tentu rimbanya. Orde Baru juga sangat keras terhadap radikalisme kanan. Di antara yang paling menonjol adalah isu Komando Jihad di pertengahan tahun 1980-an. Banyak tokoh Islam yang diidentifikasi sebagai pemimpin atau anggota Komando Jihad yang ditangkap dan ditahan. Usaha untuk memberangus gerakan-gerakan radikal Islam itu pun terus berlangsung sampai periode munculnya Ikatan Cendekiawan Muslim Indonesia (ICMI) di pertengahan tahun 1990-an. Abdul Aziz Thaba membuat tipologi hubungan antara Islam dan Negara dalam tiga kategori, yaitu hubungan antara Islam dan Negara yang bercorak antagonistis, resiprokal kritis, dan hubungan antara Islam dan Negara yang saling membutuhkan. Hubungan antagonistis terjadi di awal Orde Baru sampai awal tahun 1980-an dan hubungan simbiosis terjadi di era tahun 1990- 
an (Abdul Aziz Thaba, 1995). Di era reformasi, jika gerakan radikal kiri berada dalam keadaan mati suri, tidak demikian halnya dengan gerakan radikalisme kanan. Setelah kran-kran kebebasan demokrasi dibuka, tidak serta merta membuat gerakan radikal ini surut, bahkan tumbuh subur, seperti munculnya Hizbut Tahrir Indonesia (HTI), Majelis Mujahidin Indonesia (MMI), Front Pembela Islam (FPI), Gerakan Salafi, Laskar Jundullah, Lasykar Jihad, Gerakan Islam Ahlussunnah wal Jamaah, Jamaah Ansharut Tauhid (JAT), Negara Islam Indonesia (NII) dan berbagai agama bercorak lokal adalah sebuah potret merebaknya gerakan-gerakan keagamaan ini.

Kedua, faktor emosi keagamaan. Harus diakui bahwa salah satu penyebab gerakan radikalisme adalah faktor sentimen keagamaan, termasuk di dalamnya adalah solidaritas keagamaan untuk kawan yang tertindas oleh kekuatan tertentu. Lebih tepat dikatakan hal itu sebagai faktor emosi keagamaannya dan bukan agama (wahyu suci yang absolut), karena gerakan radikalisme selalu mengibarkan bendera dan simbol agama seperti dalih membela agama, jihad, dan mati sahid. Dalam konteks ini yang dimaksud dengan emosi keagamaan adalah agama sebagai pemahaman realitas yang sifatnya interpretatif, yakni nisbi dan subjektif.

Keterlibatan faktor emosi keagamaan ini nyata ditunjukkan dengan terjadinya kerusuhan massal di awal reformasi, ratusan gereja dan tempat usaha etnis Cina dibakar, dirusak, dan dijarah. Pada bulan Mei 1998 kerusuhan bernuansa SARA menewaskan lebih dari 1000 orang. Kerusuhan Timor Timur, Poso, Ambon, Sambas, dan lainnya adalah sebagian dari daftar panjang kerusuhan yang dilatari oleh konflik agama dan etnik (Budhy Munawar-Rahman, 2010: LVII). Kekerasan yang baru saja terjadi misalnya kekerasan kelompok FPI dengan Ahmadiyah di Cikeusik, kerusuhan di Temanggung, Lombok, dan kerusuhan Syiah dan NU di Madura yang berlatar agama.

Ketiga, faktor kultural ini juga memiliki andil yang cukup besar yang melatarbelakangi munculnya radikalisme. Hal ini wajar karena memang secara kultural, sebagaimana diungkapkan Musa Asy’ari (Musa Asy’arie, 1992 :95), bahwa di dalam masyarakat selalu diketemukan usaha untuk melepaskan diri dari jeratan jaring-jaring kebudayaan tertentu yang dianggap tidak sesuai. Sedangkan yang dimaksud faktor kultural di sini adalah sebagai antitesis terhadap budaya sekularisme. Budaya Barat merupakan sumber sekularisme yang dianggap sebagai 
musuh yang harus dihilangkan dari bumi. Sedangkan fakta sejarah memperlihatkan adanya dominasi Barat dari berbagai aspeknya atas negeri-negeri dan budaya Muslim. Peradaban Barat sekarang ini merupakan ekspresi dominan dan universal umat manusia. Barat telah dengan sengaja melakukan proses marjinalisasi seluruh sendi-sendi kehidupan Muslim sehingga umat Islam menjadi terbelakang dan tertindas. Barat dengan sekularismenya sudah dianggap sebagai bangsa yang mengotori budaya-budaya bangsa Timur dan Islam sekaligus dianggap bahaya terbesar dari keberlangsungan moralitas Islam. Hal ini bisa dilihat dari perubahanperubahan sehari-hari, seperti semakin masifnya pola konsumsi umat beragama pada produk-produk Barat, misalnya ATM, handphone, internet, dan produk global lainnya (Zuly Qodir, 2011:23).

Gerakan radikal di Indonesia disinyalir Yudi Latif karena mereka tidak menerima perbedaan. Perbedaan yang muncul dimasyarakat dianggap sebagai sebuah ancaman terhadap eksistensi kaum radikal. Mereka berasumsi bahwa untuk menunjukkan eksistensi mereka maka mereka harus mengeliminasi eksistensi orang lain. Teroris berani mati karena mereka menganggap perbedaan adalah musuh dan ancaman yang harus dihancurkan. "Teroris berani mati, tetapi tidak berani hidup, mereka adalah musuh kehidupan" (Mukhlisin, 9 Maret 2012).

Keempat, faktor ideologis antiwesternisme. Westernisme merupakan suatu pemikiran yang membahayakan Muslim dalam mengaplikasikan syariat Islam, sehingga simbol-simbol Barat harus dihancurkan demi penegakan syariat Islam. Walaupun motivasi dan gerakan anti-Barat tidak bisa disalahkan dengan alasan keyakinan keagamaan tetapi jalan kekerasan yang ditempuh kaum radikalisme justru menunjukkan ketidakmampuan mereka dalam memosisikan diri sebagai pesaing dalam budaya dan peradaban. Yudi Latif menandaskan, munculnya terorisme disebabkan karena tidak berjalannya sense of conseption of justice. Teroris muncul karena munculnya skeptisisme terhadap demokrasi. Demokrasi dianggap sebagai sistem negara kafir (Mukhlisin, 9 Maret 2012).

Kelima, faktor kebijakan pemerintah. Ketidakmampuan pemerintah di negaranegara Islam untuk bertindak memperbaiki situasi atas berkembangnya frustasi dan kemarahan sebagian umat Islam disebabkan dominasi ideologi, militer maupun ekonomi dari negera-negara besar. Dalam hal ini elit-elit pemerintah di negeri- 
negeri Muslim belum atau kurang dapat mencari akar yang menjadi penyebab munculnya tindak kekerasan (radikalisme) sehingga tidak dapat mengatasi problematika sosial yang dihadapi umat. Hal yang demikian diungkapkan oleh Mahathir Muhammad dalam sambutannya pada acara pertemuan negara-negara OKI di Kuala Lumpur Malaysia tanggal 1-3 April 2002 (SOLOPOS, 2002: 4). Di negeri ini bisa dilihat tidak tuntasnya penyelesaian masalah korupsi, aset negara yang banyak lari ke luar negeri, pencaplokan wilayah Indonesia oleh Malaysia, dan disedotnya kekayaan negara oleh konspirator politik.

Di samping itu, keenam, faktor media massa (pers) Barat yang selalu memojokkan umat Islam juga menjadi faktor munculnya reaksi dengan kekerasan yang dilakukan oleh umat Islam. Propaganda-propaganda lewat pers memang memiliki kekuatan dahsyat dan sangat sulit untuk ditangkis sehingga sebagian “ekstrim” yaitu perilaku radikal sebagai reaksi atas apa yang ditimpakan kepada komunitas Muslim.Lihat misalnya film Fitna, penggambaran tentang kiamat (film 2012), dan lainnya.

\section{Respons terhadap Radikalisme Islam Indonesia}

Akibat media massa (pers) Barat yang selalu memojokkan umat Islam menjadi faktor munculnya reaksi dengan kekerasan yang dilakukan oleh umat Islam. Di samping Muslim sendiri masih belum selesai menata identitas diri, tema-tema yang diusung kelompok Islam radikal kerap kali menerapkan syariah Islam dalam negara yang dinilai Barat sangat "menakutkan". Tema tersebut akan berakibat kepada kecurigaan dunia internasional yang merugikan bagi bangsa Indonesia, apalagi bila dihadapkan pada pelaku bom alumni Pondok Pesantren al-Mukmin Ngruki Surakarta; Muchlas alias Ali Gufron, Amrozi, Fathurrahman al-Ghazi (ditangkap di Filipina), Asmar Latinsani (pelaku bom bunuh diri JW Mariot), dan lain-lain.

Kekerasan bukanlah tipe agama-agama. Agama selalu menerapkan doktrin keselamatan dan kesejahteraan. Peter L. Berger sebagaimana dikutip Nur Syam, menawarkan dua konsep penting supaya tidak terjadi kekerasan agama, religious revolution, dan religion subcultures (Nur Syam, 2005: 94). Arahan pertama terkait dengan bagaimana elite agama dapat menumbuhkan dengan cepat kesadaran akan pentingnya model agama yang modern. Di dalam agama yang modern ditandai dengan adanya penghargaan terhadap pluralitas yang tidak vakum diversitas dan 
vakum budaya. Manusia hidup dalam entitas yang heterogen. Maka agama akan menjadi mode of comunication yang tidak hanya vertikal tetapi juga horizontal. Agama sebagai model komunikasi berarti menuntut kesepahaman dan mengakui perbedaan dalam banyak hal tetapi juga memiliki kesamaan misi kemanusiaan.

Religion subcultures yaitu gerakan elit agama untuk mencegah pengaruh luar agama masuk ke dalam wilayah agama. Faktor ekonomi dan politik adalah dua faktor yang sering mengintervensi kehidupan keberagamaan. Agama sebenarnya merupakan persoalan moralitas dan politik ekonomi merupakan persoalan yang profan. Keduanya harus diletakkan dalam wilayah yang berbeda.

\section{Penutup}

Praktik kekerasan (radikalisme) yang dilakukan oleh sekelompok umat Islam di Indonesia tidak dapat dialamatkan kepada Islam saja sehingga propaganda media Barat yang memojokkan Islam dan umat Islam secara umum tidak dapat diterima. Islam tidak mengajarkan radikalisme, tetapi perilaku kekerasan sekelompok umat Islam atas simbol-simbol Barat memang merupakan realitas historis-sosiologis yang dimanfaatkan media pers Barat untuk memberi label dan mengampanyekan antiradikalisme Islam.

Identitas keislaman (kesadaran umum sebagai Muslim) memang menjadi identitas yang tepat dan referensi yang efektif bagi gerakan radikalisme. Tetapi faktor eksternal yaitu dominasi dan kesewenang-wenangan Barat atas negeri-negeri Muslim merupakan faktor yang lebih dominan yang memunculkan radikalisme Muslim sebagai reaksi. Jadi jelas, bahwa radikalisme muncul dari kebanggan (identitas keislaman) yang terluka (oleh Barat), kekuatan media Barat dalam merepresentasi Islam, tekanan politik penguasa terhadap keberadaannya, emosi keagamaan, faktor kultural, tidak menerima perbedaan, ideologis anti westernisme, dan faktor kebijakan pemerintah.

Solusi-solusi yang muncul harus dapat mencakup kompleksitas permasalahan

yang kesemuanya harus berangkat dari kearifan para pemimpin Barat dan juga negeri-negeri Muslim untuk mampu membaca fenomena perkembangan zaman yang mencerminkan aspirasi dari kalangan Muslim. Di samping itu, perlu dipertimbangkan konsep penting religious revolution dan religion subcultures yang ditandai dengan adanya penghargaan terhadap pluralitas dan mendudukkan kondisi 
sosial-politik dan ekonomi supaya tidak terjadi kekerasan agama. Jika tidak, maka Islam yang damai akan termanifestasi dalam bentuk radikalisme yang penuh kekerasan seperti yang diungkapkan Harris dalam The End of Faith di atas.

\section{Daftar Pustaka}

Abdul Aziz Thaba. (1995). Islam dan Negara dalam Politik Orde Baru. Jakarta: Gema Insani Press.

Ahmed, Akbar S. (1993). Posmodernisme, Bahaya dan Harapan bagi Islam. Terjemah M. Sirozi. Mizan: Bandung.

Amin Abdullah. (1996). Studi Agama, Normatifitas atau Historisitas? Yogyakarta: Pustaka Pelajar.

Azyumardi Azra. (1996). Pergolakan Politik Islam, dari Fundamentalis, Modernisme hingga Post-Modernisme. Jakarta: Paramadina.

Budhy Munawar-Rahman. (2010). Argumen Islam untuk Liberalisme: Islam Progresif dan Perkembangan Diskursusnya. Jakarta: Grasindo.

Gibb, H.A.R. (1990). Aliran-aliran Moderen dalam Islam. Terjemah oleh Machnun Husein. Jakarta: Rajawali Press.

Imarah, Muhammad. (1999). Fundamentalisme dalam Perspektif Pemikiran Barat dan Islam. Terjemah oleh Abdul Hayyie al-Kattani. Jakarta: Gema Insani Press.

Kuntowijoyo. (1997). Identitas Politik Umat Islam. Bandung: Mizan.

M. Zaki Mubarak (2008). Genealogi Islam Radikal di Indonesia: Gerakan, Pemikiran dan Prospek Demokrasi. Yogyakarta: Pustaka LP3ES.

Mukhlisin, Bahaya Radikalisme, http://icrp-online.org/112011/post-804.html, diakses 9 Maret 2012.

Musa Asy’arie. (1992). Manusia Pembentuk Kebudayaan dalam Al-Qur'an. Yogyakarta: LESFI.

Nasution, Harun. (1995). Islam Rasional. Bandung: Mizan.

Nur Syam. (2005). Bukan Dunia Berbeda: Sosiologi komunitas Islam. Surabaya: Eureka.

Nurcholish Madjid. (1995). Pintu-Pintu Menuju Tuhan. Jakarta: Paramadina. 
-------------. (1995). Islam Agama Peradaban, Mencari Makna dan Relevansi Doktrin Islam dalam Sejarah. Jakarta: Paramadina.

Rahman, Fazlur. (1982). Islam and Modernity. Chicago: The University of Chicago Press.

(2001). "Pendekatan terhadap Islam dalam Studi Agama" dalam Richard C. Martin, Pendekatan Kajian Islam dalam Studi Agama. Terjemah oleh Zakiyuddin Baidlawi. Surakarta: Muhammadiyah University Press.

Riddel, Peter G. (2002). "The Diverse Voices of Political Islam in Post-Suharto Indonesia", Islam and Christian-Muslim Relations. Vol. 13, No. 1.

Shaban. (1994). Islamic History.(Cambridge: Cambridge University Press.

Watt, William Montgomery. (1988). Islamic Fundamentalism and Modernity. London: T.J. Press (Padstow) Ltd.

Zuly Qodir. (2011). Sosiologi Agama: Esai-esai Agama di Ruang Publik. Yogyakarta: Pustaka Pelajar. 